\title{
ІНЖЕНЕРНО-ТЕХНІЧНА ОСВІТА І НАУКА: ЗДОБУТКИ ТА ПЕРСПЕКТИВИ
}

\begin{abstract}
Проаналізовано здобутки інженерно-технічної освіти і науки в НЛТУ України. Коротко висвітлено історію формування Навчально-наукового інституту інженерної механіки, автоматизації та комп'ютерно-інтегрованих технологій. Окреслено спеціальності, за якими в інституті готують бакалаврів, магістрів і докторів філософії. Розглянуто структуру інституту, його кадрове та матеріально-технічне забезпечення. Викладено інформацію про участь фахівців інституту в розроблянні проектів стандартів вищої освіти України для бакалаврського й магістерського рівнів та в удосконалюванні науково-технічної термінології. Подано результати впровадження наскрізної програми екологізування навчального процесу. Наголошено на важливості застосування матеріальної бази курсів готування водіїв транспортних засобів для навчання студентів за спеціальностями інституту. Охарактеризовано оригінальні наукові школи, основні наукові проблеми та напрями досліджень. Розглянуто доробок науковців інституту за десятирічний термін. Виокремлено важливість проведення освітянської та наукової діяльності у співпраці з галузевими підприємствами. Висвітлено складники міжнародної співпраці для розвивання інженернотехнічної освіти. Викладено перспективи розвивання її в НЛТУ України для фахівців лісового господарства, деревообробної та меблевої промисловості.
\end{abstract}

Ключові слова: інженерно-технічна освіта; наука; здобутки; перспективи.

Присвячено черговому ювілеєві НЛТУ України Велич його в людських мозолях Кожного, хто його зростив, В тих, хто не встиг пожить доволі Й тих, хто сьогодні повний сил.

Вступ. 3 часу заснування Крайової школи лісового господарства у Львові (січень 1874 р.) ii учні вивчали інструменти, пристрої та механізми для ведення лісового господарства. Однак початком цілісної інженернотехнічної освіти в царині лісового господарства й деревообробної галузі було 15 січня 1945 р., коли було ухвалено постанову уряду УРСР про організування Львівського лісотехнічного інституту з початковою структурою: Лісоінженерний факультет (зі спеціальностями "Механізація лісорозробок", "Лісотранспорт", "Лісоексплуатація"); Факультет механічної технології деревини (зі спеціальностями "Лісопиляння", "Меблеве виробництво", "Фанерне виробництво"); Лісоінженерноекономічний факультет (Tunytsia, et al., 2014). Цей навчальний заклад створено, щоб готувати інженерні кадри для заготовляння та механічного обробляння деревини.

У 1988 р. на базі реорганізованих упродовж низки років факультету механічної технології деревини та лісоінженерного факультету було створено лісомеханічний факультет (ЛМФ). Від березня 2014 р. ЛМФ отримав статус Навчально-наукового інституту інженерної механіки, автоматизації та комп'ютерно-інтегрованих технологій (НHI IMAKIT).

Викладення основного матеріалу. У НHI IMAКIT сьогодні готують бакалаврів і магістрів за такими спеціальностями: 131 "Прикладна механіка", 133 "Галузеве машинобудування", 151 "Автоматизація та комп'ютерно-інтегровані технології", 205 "Лісове господарство" (освітня програма "Лісова інженерія"); докторів філософіï - за спеціальностями 133 "Галузеве машинобудування"; 151 "Автоматизація та комп'ютерно-інтегровані технології".

Упродовж останніх 25 років підготовлено понад 2,1 тисячі фахівців стаціонарної та понад 1,7 тисячі заочної форми навчання. Серед випускників НHI IMAКIT - постійний представник України в Раді Європи, два посли України, два віце-прем'єр-міністри, два міністри економіки України, один міністр, заступники міністра лісової та деревообробної промисловості України і Молдови, заступник голови Державного комітету лісового господарства України, 17 докторів наук (професорів) і понад 100 кандидатів технічних наук (доцентів).

Сьогодні інженерно-технічну освіту в інституті забезпечують шість кафедр: лісопромислового виробниц-

\section{Інформація про авторів:}

Ребезнюк Ігор Тарасович, д-р техн. наук, професор, директор Навчально-наукового інституту інженерної механіки, автоматизації та комп'ютерно-інтегрованих технологій. Email: rebeznyuk@nltu.edu.ua; https://orcid.org/0000-0001-5924-7700

Цитування за ДСту: Ребезнюк І. Т. Інженерно-технічна освіта і наука: здобутки та перспективи. Науковий вісник НЛтУ України. 2019, т. 29, № 10. С. 45-448.

Citation APA: Rebezniuk, I. T. (2019). Engineering and technical education and science: achievements and perspectives. Scientific Bulletin of UNFU, 29(10), 45-48. https://doi.org/10.36930/40291008 
тва та лісових доріг (завідувач канд. техн. наук доц. Бакай Б. Я.), лісових машин (завідувач канд. техн. наук доц. Стиранівський О. А.), деревообробного обладнання та інструментів (завідувач д-р техн. наук проф. Шостак В. В.), автоматизації та комп'ютерно-інтегрованих технологій (завідувач д-р техн. наук проф. Поберейко Б. П.), прикладної механіки (завідувач д-р техн. наук проф. Лютий $€$. М.), технології матеріалів і машинобудування (завідувач д-р техн. наук проф. Голубець В. М.).

Загалом на кафедрах працюють 57 викладачів, 3 яких: 10 професорів та 27 доцентів і кандидатів наук. Серед них: заслужений працівник освіти України, професор М. Г. Адамовський; лауреати державних і республіканських премій - заслужений діяч науки і техніки України, професор В. М. Голубець та доцент В. І. Степанишин; відмінники освіти України професори Н. І. Библюк та В. В. Шостак. Наукові ступені та вчені звання мають 72 \% науково-педагогічних працівників. Вони за десятилітній період опублікували 223 навчально-методичні розробки: чотири підручники, 27 навчальних посібників, 18 конспектів лекцій та 174 навчально-методичних вказівок і рекомендацій. 3 2017 р. для покращення якості готування фахівців до освітньо-професійних програм введено 21 нову навчальну дисципліну.

Для навчання студентів обладнано 12 лекційних аудиторій, 27 навчальних лабораторій, 21 спеціалізованих кабінетів, 10 науково-дослідних лабораторій та навчальний полігон. Загальна площа навчальних приміщень становить майже $2500 \mathrm{~m}^{2}$, польових лабораторій $1120 \mathrm{~m}^{2}$, навчального полігона - близько 6 тис. м², парку дорожніх і транспортних машин $-520 \mathrm{~m}^{2}$.

В інституті відповідно до університетського напряму діяльності за гаслом "Вчимося жити в гармонії 3 природою" розроблено і впроваджено наскрізну програму екологізації навчального процесу зі всіх спеціальностей та освітніх програм, відповідно до якої частка екологічних аспектів у робочих програмах дисциплін становить 4,3-7,6 \% від загального обсягу навчального матеріалу.

За сприяння ТОВ Клінкманн Україна (м. Київ), офіційного дистриб'ютера засобів автоматизації фірми Unitronics (Ізраїль), 29 травня 2018 р. на кафедрі автоматизації та комп'ютерно-інтегрованих технологій введено в дію новітню навчально-наукову лабораторію промислових контролерів зі шістьма стендами для вивчення та дослідження систем автоматичного керування технологічними процесами, що відповідає сучасним тенденціям розвитку світової науки і техніки.

В інституті працюють курси готування водіїв транспортних засобів, де від 1995 р. підготовлено понад 1500 осіб, з-поміж яких близько 50 \% студентів нашого університету. Матеріальну базу цих курсів успішно використовують і для навчання студентів за спеціальностями 131 "Прикладна механіка" і 133 "Галузеве машинобудування".

Фахівці інституту входять до складу науково-методичної підкомісії 133 "Галузеве машинобудування" НМК 9 з інженерії сектора вищої освіти Науково-методичної ради Міністерства освіти і науки України та є розробниками проектів стандартів вищої освіти України для бакалаврського й магістерського рівнів зі спеці- альності 133 "Галузеве машинобудування" в галузі знань 13 "Механічна інженерія".

Працівники ННI IMАКІТ досліджують науково-технічну термінологію, беруть участь у міжнародних термінологічних конференціях. Вони опублікували низку науково-методичних статей щодо української термінології. П'ятеро науковців інституту взяли участь у складі авторського колективу в готуванні Лісотехнічного українсько-російсько-англійського термінологічного словника (Tunytsia, \& Bohuslaieva, 2014). Професор Ребезнюк I. Т. очолює підкомітет "Лісове господарство та деревинообробче устатковання" Технічного комітету стандартизації науково-технічної термінології Міністерства економічного розвитку і торгівлі та Міністерства освіти і науки України.

Інженерно-технічну науку в інституті розвивають за 19 основними науковими проблемами, як-от:

1. Технології сталого лісокористування, збереження і збагачення довкілля.

2. Розроблення технологій та устатковання для раціонального природокористування.

3. Моделювання та прогнозування стану об'єктів промислового машинобудування та довкілля.

4. Динаміка лісових машин.

5. Екологічні технології лісоексплуатування.

6. Програмне забезпечення проектування i розрахунку вузлів самохідних лісових машин.

7. Засади раціоналізації процесів лісозаготівлі з використанням гідроприводу та відповідних джерел енергії для зменшення теплових втрат.

8. Зміцнення дереворізальних інструментів та їхнє підготовлення.

9. Ефективна утилізація деревинних відходів.

10. Екологізація технічних систем.

11. Підвищення точності пиляння деревини.

12. Обгрунтування параметрів стрічковопилкових верстатів.

13. Обгрунтування структури ремонтного циклу деревообробних верстатів.

14. Підвищення ефективності функціонування автоматизованих виробничих систем

15. Неруйнівний контроль фізико-механічних характеристик деревини та деревинних матеріалів.

16. Розроблення канатних систем для лісового комплексу та підвищення надійності їх основних елементів.

17. Пневмотранспортні системи деревообробних підприємств.

18. Дослідження процесів абразивного оброблення деревини, деревних та інших матеріалів.

19. Розроблення методів зміцнення деталей машин, інструменту і технологічного процесу.

Завдяки високому рівню наукових досліджень i спадкоємності поколінь в інституті сформовано оригінальні наукові школи та напрями досліджень. Заслужене визнання набула школа 3 проблем розробки наукових основ моделювання й автоматизації складних виробничих систем лісового комплексу, біля витоків якої стояли доктори технічних наук, професори Б. Г. Гастєв та I. B. Батін.

Під керівництвом д-ра техн. наук Б. Г. Гастєва на очолюваній ним кафедрі сухопутного і водного транспорту лісу від п'ятдесятих років минулого сторіччя почала розвиватися і набула широкого визнання наукова школа динаміки лісотранспортних машин. Основні 
постулати теорії науковець виклав у 1967 р. у праці "Основи динаміки лісовозного рухомого складу". Професор Батін I. В. заклав засади автоматизації виробничих процесів у лісовій і деревообробній промисловості та наукової школи з моделювання й оптимізування недетермінованих виробничих процесів і теорії автоматичних ліній.

Однією з найбільш представницькою є школа докторів технічних наук М. В. Плаксіна, Н. М. Бєлої, Т. М. Шкіpi. Ïї відомо завдяки розробленням екологічно невиснажливих та енергоощадливих технологій лісозаготівельного виробництва. Вагомі здобутки школа має в таких напрямах: оптимізація виробничих процесів лісозаготівельного виробництва, розроблення линвових установок для транспортування деревини в гірських умовах. Розвиток наукової школи линвового транспорту лісу насамперед пов'язаний з ім'ям завідувача кафедри будівельної механіки, доктора технічних наук, професора Наталії Михайлівни Бєлої.

Заслужене визнання в Україні і за іiі межами свого часу набула технологія та інструмент для абразивного оброблення деревини та композитних матеріалів, розроблені під керівництвом д-ра техн. наук, ректора Львівського лісотехнічного університету, професора А. І. Яцюка та старшого наукового співробітника О. Я. Густі. Роботу науковців вперше в інституті було нагороджено Державною премією в галузі науки і техніки.

Від 1983 р. в інституті функціює наукова школа: "Дослідження сучасних методів підвищення періоду стійкості дереворізальних інструментів та розроблення техніки і технології для їх застосування". Фундаторами цієї школи є д-р техн. наук, проф. Кірик М. Д. (19492014 р.)., д-р техн. наук, проф. Голубець В. М. Проблеми щодо зміцнювання та готування дереворізального інструменту й раціонального переробляння деревини також вивчали професор С. М. Тімонен і доценти В. М. Фелещук, Н. М. Серебряний.

В інституті працює спеціалізована вчена рада Д 35.072 .03 (голова д-р техн. наук проф. I. Т. Ребезнюк), на засіданнях якої за останні десять років захищено дві докторські та 17 кандидатських дисертацій.

Упродовж багатьох років функціюють кафедральні та галузеві науково-дослідні лабораторії, зокрема: лабораторія шліфування деревини та деревинних матеріалів, лабораторія неруйнівного контролю та лабораторія лісових доріг і лісотранспортних засобів, які поставляють замовникам дослідні зразки абразивних інструментів, дефектоскопів та розробляють проекти лісових доріг. Започатковано лісотранспортне планування з розробленням інтерактивної карти мережі доріг лісових масивів.

32008 р. науковці інституту виконали 13 держбюджетних та 59 госпдоговірних науково-дослідних робіт на загальну суму понад 2,3 млн грн. За результатами їхнього виконання опубліковано 11 монографій, три словники, 534 наукових статті, 192 тези науково-технічних конференцій, 76 звітів 3 держбюджетної та госпдоговірної тематики, отримано 61 охоронний документ на об'єкти права інтелектуальної власності. Розроблено понад 60 проектів лісових доріг (останніми роками близько 10 проектів щорічно).
Наукова діяльність інституту тісно пов'язана з галузевими підприємствами. Від травня 2015 р. ННІ IMАКІТ є дійсним членом Української асоціації деревообробного обладнання (УАДО) (Kataloh, 2018), у 20152018 р. - член правління цієї асоціації.

Міжнародну співпрацю інституту зорганізовано 3 низкою закордонних партнерів за спорідненістю спеціальностей і напрямів наукових досліджень. Партнерами інституту є: Технічний університет Зволена (Словаччина), Університет в Любляні (Словенія), Аграрний університет (м. Краків, Польща), Німецький дослідницький центр з біомаси (м. Лейпциг), Інститут фізики твердого тіла (м. Леобен, Австрія), Сільськогосподарський університет (м. Брно, Чехія), Лісовий університет (м, Брно, Чехія), Сільськогосподарський університет (м. Прага, Чехія), Люблінський політехнічний університет (Польща), Білоруський державний технологічний університет. У 2018 р. два викладачі кафедри лісових машин (ЛМ) пройшли стажування у технічному університеті Зволена за програмою "Еразмус+".

Працівники інституту брали участь у спільному українсько-німецькому проекті UK 10/040 "Розвиток інфраструктури з використання біомаси для виробництва біогазу", 2016 р. та спільному міжнародному проекті TREC DANUBE $з$ раціонального використання деревної біомаси для енергетичних потреб (Німеччина, Україна, Чехія, Польща, Словаччина, Угорщина, Румунія, Молдова, Болгарія), 2016 р.

У 2019 р. за допомогою ТОВ "МОСТ-Україна" заплановано створити, на базі новітнього обладнання, пристроїв та інструментів виробництва американської компанії "Wood-Mizer", навчально-технічний центр дуальної освіти при кафедрі деревообробного обладнання та інструментів ННI IMАКIT.

Висновок. Перспективними напрямами розвивання інженерно-технічної освіти і науки в царинах лісового господарства, деревообробної та меблевої промисловості $€$ :

• поглиблення співпраці ННI IMАКІТ з Українською асоціацією деревообробного обладнання $з$ метою підвищення якості проведення наукових досліджень та рівня практичної підготовленості фахівців;

- розширення міжнародної співпраці інституту з вищими навчальними закладами, втілюючи програми академічної мобільності;

- підвищення ефективності подання заявок колективом НHI IMАКІТ на отримання зарубіжних грантів у проектах Європейського Союзу, зокрема у програмах "ERASMUS+" та "Horizont

\section{References}

Kataloh. (2018). Ukrainska asotsiatsiia derevoobrobnoho obladnannia, (Vol. 1, 2016, 22 p., Vol. 2, 2017, 28 p., Vol. 3, 2018, 36 p.). Kyiv: UADO. [In Ukrainian].

Tunytsia, Yu. Yu., \& Bohuslaieva, V. O. (Eds). (2014). Lisotekhnichnyi terminolohichnyi slovnyk: ukrainskyi, rosiiskyi, anhliiskyi. Lviv: Piramida, 967 p. [In Ukrainian].

Tunytsia, Yu. Yu., et al. (Eds). (2014). Natsionalnyi lisotekhnichnyi universytet Ukrainy. Istorychne prezentatsiine vydannia. Kyiv: TOV "Lohos Kyiv", 248 p. [In Ukrainian]. 


\section{ENGINEERING AND TECHNICAL EDUCATION AND SCIENCE: ACHIEVEMENTS AND PERSPECTIVES}

The paper analyses the achievements of engineering and technical education and science in UNFU of Ukraine. The history of the formation of the Educational-Scientific Institute of Engineering Mechanics, Automation and Computer-Integrated Technologies are briefly described. The specialities of training bachelors, masters and doctors of philosophy in the Institute are outlined. The structure of the Institute, which currently comprises six departments, and its personnel potential are described. The material and technical provision is characterized. We also highlight the creation of the newest educational-scientific laboratory of industrial controllers with six stands for studying and researching the systems of automatic control of technological processes, which corresponds to modern trends in the development of world science and technology. The article also describes the participation of specialists of the Institute in the development of draft standard for higher education in Ukraine for bachelor's and master's degrees. The work of scientists on the improvement of scientific and technical terminology together with the Technical Committee for Standardization of Scientific and Technical Terminology is highlighted. The results of the implementation of a through program of ecologization of the educational process according to the university's direction of activity under the slogan "Learning to live in harmony with nature" are presented. We note the importance of using the material base of vehicles drivers training courses for training students in the specialities of the institute as well. The original scientific schools, department and branch research laboratories, the main scientific problems and research directions, most of which have an ecological orientation, are described. The achievements of scientists of the Institute for ten years period are considered. The importance of educational and scientific activities conducted in cooperation with branch enterprises, both foreign and domestic, in particular with the Ukrainian Association of Woodworking Equipment, is singled out. The components of international cooperation for the development of engineering and technical education are defined. The prospects of its development in UNFU of Ukraine for specialists of forestry, woodworking and furniture industry are outlined.

Keywords: engineering and technical education; science; achievements; perspectives. 